\title{
大腸癌の静脈侵襲に関する臨床病理学的研究
}

\author{
岐阜大学医学部臨床梭査医学教室

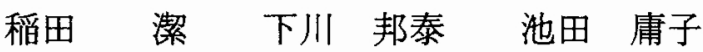 \\ 岐阜大学医学部第 1 外科教室 \\ 林勝 知 後藤 全宏

\section{CLINICOPATHOLOGICAL STUDY ON VENOUS INVASION IN COLORECTAL CARCINOMA}

\section{Kiyoshi INADA, Kuniyasu SHIMOKAWA and Tsuneko IKEDA} \\ Department of Clinical Laboratory Medicine, Gifu University School of Medicine

\section{Masatomo HAYASHI and Masahiro GOTO} \\ First Department of Surgery, Gifu University School of Medicine \\ 最近 5 年間の大腸癌切除例のらち $\mathrm{m}$ 癌を除く 176 例について, ビクトリアブルーーへマトキシリン \\ エオシシン染色を行い，静脈侵襲の頻度と意義を検索した。静脈侵襲は98例（55.6\%）に認められ，侵

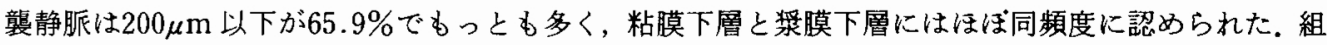 \\ 織型では低分化腺癌で $66.6 \%$ 之高率で，高拉よび中分化腺癌では $53.7 \%$ と $57.5 \%$ で差がなかった，肝 \\ 転移のある24例中 23 例に静脈侵襲が認められ，両者の密接な関係が示された。静脈侵襲陽性例の 5 生 \\ 率は35\%で，陰性例の $62 \%$ に比べ有意に不良であった，大腸癌では胃癌よりも静脈侵襲の意義が大き
} いこと，その検索に本染色法が有用なことを指摘した。

索引用語：大腸癌静脈侵襲，ビクトリアブルーーヘマトキシリン・エオシン重染色

はじめに

社会環境の欧米化にともない日本人の悪性腫瑒の種 類, 頻度が変化しつつあり, 消化器癌では胃癌の減少, 逆に大腸癌の増加が注目されている，大腸癌は胃癌よ り予後は良好であるが，それを左右するのは血行性転 移，とくに肝転移であることはよく知られている。し たがって，肝転移を予知しその発生を予防ないし抑制 することは，大腸癌の治療成續の向上に必須である。 このため, 肝転移の源となる原発巣の病理組織像, と くに血管侵襲について種々検討されているが，いまだ 一致した見解はなくさらに詳細な検索が必要である。 著者らはこの点に着目し, 大腸癌切除標本について静 脈侵襲の有無, 程度を検索しその臨床的意義を検索し た.

検查対象および方法

岐阜大学医学部第 1 外科教室に扮いて, 昭和 56 年上

$<1988$ 年 5 月 11 日受理 $>$ 別刷請求先：稲田 潔

T500 岐阜市司町 40 岐阜大学臨床検查医学教室
り同60年にいたる満 5 年間に切除された大腸癌は 185 例で，そのうち，癌浸潤が粘膜内に限局する 9 例を除 く176例(結腸癌77例, 直腸癌99例)について検索した。 病理組織学的検査は, 癌腫の浸潤の最深部通り腫瘍 の全長にわたる組織片を切り出し，多くの場合 1 個，

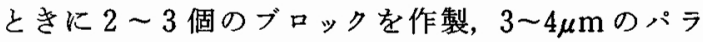
フィン切片について通常の Hemotoxylin-eosin 染色 (以下 HE 染色) と, Victoria blue-hematoxylin-eosin 重染色 (以下 VB-HE 染色) ${ }^{1}$ を行い，静脈侵襲に重点 をおいて大腸癌取扱い規約2)にしたがって検索した。 なお, 画像解析装置 (Color Image Analyzer, CIA-IO, オリンパス社製）により静脈の大ささ（短径）を測定 した。また，術後長期にわたり経過を追求し予後を調 查した。

推計学的有意差検定は $\chi^{2}$ 検定, 累積生存率は生命保 険数理法により求めた。

\section{結 果}

1. 静脈侵襲の頻度と程度

176 例中 98 例 $(55.6 \%$ ) に静脈侵襲が認められた。そ 
の程度を数により， 1 切片に 1 ～個認められるもの を $\mathrm{V}_{1}, 3 \sim 6$ 個のものを $\mathrm{V}_{2}, 7$ 個以上を $\mathrm{V}_{3}$ とすると, その頻度はそれぞれ64，23，11となり， $\mathrm{V}_{1}$ が注は分 の 2 を占めもっとも多かった（表 1 ）.

\section{2. 侵襲静脈の大ささと頻度}

腫湟の侵襲をうけた静脈を, 短径 $200 \mu \mathrm{m}$ 以下を $\mathrm{S}$, $200 \mu \mathrm{m} \sim 1 \mathrm{~mm}$ を $\mathrm{M}, 1 \mathrm{~mm}$ 以上を $\mathrm{L}$ と分類し，大きさ の異なるものが 2 種以上認められた 25 例では，その種 類を別個にかで党，計135個について大きさ別の出現頻 度を求めた. S が89(65.9\%), M が41(30.4\%), L が $5(3.7 \%)$ となり，Sがもっとも多く，ルーペないて 肉眼でも識別しらるLは少数にすぎなかった（表 2).

\section{3. 侵襲静脈の局在}

癌細胞の侵襲をらけた静脈は粘膜下層, 筋層, 浆膜 下層ないし壁外（直腸）のいずれにもみられ，5ち20 例では 2 層以上にわたって認められた（18例で 2 層, 2 例で 3 層)．重複した 20 例 22 局在を加えた 120 個の静

表 1 静脈侵襲（v）の頻度と程度

\begin{tabular}{ll}
\hline$v$ & 例数 \\
\hline$v_{1}$ & 64 \\
$v_{2}$ & 23 \\
$v_{3}$ & 11 \\
\hline & $98 / 176(55.6 \%)$
\end{tabular}

表 2 侵襲静脈の大ささと頻度

\begin{tabular}{cc}
\hline 大きさ & 例 数 $(\%)$ \\
\hline $\mathrm{S}$ & $89(65.9 \%)$ \\
$\mathrm{M}$ & $41(30.4 \%)$ \\
$\mathrm{L}$ & $5(3.7 \%)$ \\
\hline 計 & $135(100 \%)$ \\
& $*$ 重複25例37個
\end{tabular}

表 3 侵襲静脈の局在部位

\begin{tabular}{lr}
\hline 部 位 & 例 数 $(\%)$ \\
\hline Submucosa & $53(44.1 \%)$ \\
Muscularis prop & $15(12.5 \%)$ \\
$\begin{array}{c}\text { Subserosa or } \\
\text { extramural }\end{array}$ & $52(43.3 \%)$ \\
\hline & $120(100 \%)$ \\
& $*$ 重複20例22局在
\end{tabular}

脈の部位は, 粘膜下層と浆膜下層（壁外を含む）がそ れぞれ53と52で，ほ注同頻度に多く，筋層でもっとも 少なかった(表 3)。なお, 静脈の大ささと局在の関係 をみると, $\mathrm{S}$ は粘膜下層でもっとも多く， M の大多数 （41中35）とLはすべて浆膜下層ないし壁外にあった。

\section{4. 組織型と静脈侵襲}

癌の組織型と静脈侵襲の関係は, 例数が少ないが低 分化腺癌が 9 例中 6 例 $(66.6 \%$ ) でもっと頻度が高 く, ついで中分化腺癌が73例中42例 (52.5\%), 高分化 腺癌が 80 例中 43 例 $(53.7 \%)$ と高く，粘液癌は 11 例中 4 例（36.3\%）ともっとも低かった。 またその他の型 (印環細胞癌 2 例, 腺扁平上皮癌 1 例)はすべて陽性で あった（表 4 ）.

\section{5. 癌深達度と静脈侵襲}

静脈侵襲は $\mathrm{sm}$ 癌で 9 例中 2 例 $(28.5 \%), \mathrm{pm}$ 癌で 21例中 5 例(23.8\%)に認められ前者より低いが，ss あ るいは $\mathrm{a}_{1}$ 以上の進行癌では陽性率は著明に高く, 深達 度と平行関係が認められた（表 5 ）。

表 4 組織型と v 因子

\begin{tabular}{cc}
\hline 組織型 & 例 \\
\hline $\mathrm{tub}$ 数(\%) \\
$\mathrm{tub} \mathrm{b}_{2}$ & $43 / 80(53.7 \%)$ \\
por & $42 / 73(57.5 \%)$ \\
$\mathrm{muc}$ & $6 / 9(66.6 \%)$ \\
その他 & $4 / 11(36.3 \%)$ \\
\hline & $3 / 3(100 \%)$ \\
\hline
\end{tabular}

表 5 深達度とv 因子

\begin{tabular}{cc}
\hline 深達度 & 例 \\
\hline $\mathrm{sm}$ & $2 / 6$ 数 $(\boldsymbol{x})$ \\
$\mathrm{pm}$ & $5 / 21(28.5 \%)$ \\
$\mathrm{ss} \cdot \mathrm{a}_{1}$ & $47 / 87(54.0 \%)$ \\
$\mathrm{s} \cdot \mathrm{a}_{2}$ & $22 / 30(73.3 \%)$ \\
$\mathrm{si} \cdot \mathrm{ai}$ & $23 / 31(70.9 \%)$ \\
\hline & $98 / 176(55.6 \%)$
\end{tabular}

表 6 ly因子とv因子

\begin{tabular}{cc}
\hline $1 y$ 因子 & 例 \\
\hline$l y_{0}$ & $11 / 35(31.4 \%)$ \\
$l y_{1}$ & $48 / 80(60.0 \%)$ \\
$l y_{2}$ & $29 / 45(64.4 \%)$ \\
$l y_{3}$ & $10 / 16(62.5 \%)$ \\
\hline
\end{tabular}


6. リンパ管侵襲と静脈侵襲

全例中リンパ管侵襲は141例 $(80.1 \%)$ に認められ, そのらちの87例 $(61.7 \%$ ) に静脈侵襲が認められた。

リンパ管侵襲のない35例でも11例 $(31.4 \%)$ に静脈侵 襲が認められたが，前者では後者に比べ著明に高い $(\mathrm{p}<0.05)$. しかし、リンパ管侵襲の程度による差は認 められなかった（表 6 ).

7.リンパ節転移と静脈侵襲

全例中記載不明の12例を除く 164 例中86例 (52.4\%) にリンパ節転移が認められ，そのらち59例（68.6\%） に静脈侵襲が認められた。リンパ節転移陰性の78例中 30例 $(38.4 \%)$ にも静脈侵襲が認められたが，転移陽 性例では高率かつ転移の程度に平行して蒿くなる傾向 があり，転移陰性例との間に有意の差 $(\mathrm{p}<0.05)$ が認 められた。

\section{8. 静脈侵襲と肝転移}

手術時に肝転移が24例 ( $\mathrm{H}_{1}$ 12例, $\mathrm{H}_{2} 6$ 例, $\mathrm{H}_{3} 6$ 例ににあったか， $5 ち 1$ 例 $\left(\mathrm{H}_{1}\right)$ をのぞく23例に原発 巣に静脈侵襲が認められ，その程度は $\mathrm{V}_{1}$ 12例 $\left(\mathrm{H}_{1} 9\right.$ 例, $\mathrm{H}_{2} 2$ 例, $\mathrm{H}_{3} 1$ 例), $\mathrm{V}_{2} 8$ 例 ( $\mathrm{H}_{1} 2$ 例, $\mathrm{H}_{2} 3$ 例, $\mathrm{H}_{3} 3$ 例), $\mathrm{V}_{3} 3$ 例 $\left(\mathrm{H}_{2} 1\right.$ 例, $\mathrm{H}_{3} 2$ 例)であった。侵竸 静脈の大ささは S 20例, M 9 例（重複 6 例），その局 在は粘膜下層 6 例，浆膜下層ないし壁外14例（重複 3 例）であった，組織型では高分化腺癌12例，中分化腺 癌 9 例，その他 3 例であった。

9. 静脈侵襲と予後

静脈侵襲陽性例のうち入院中死亡 4 例および術後経

図 1 累積生存率.

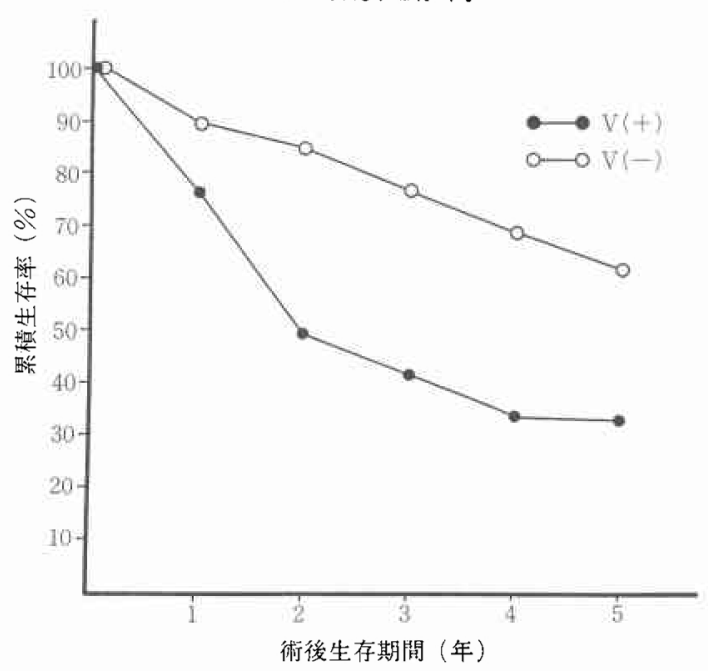

過中消息不明となった 3 例を除く91例と，陰性例78例 の累積生存率は図 1 のよらに, 陽性例で明らかに不良 で両者の間に有意の差 $(\mathrm{p}<0.001)$ が認められた。

\section{考察}

覀性腫崵の予媵にもっとも関係する血行性転移の発 生には腫湯細胞の血中への流入が前提でありここた め各種の腫汪について血管侵襲の組織学的検索が行わ れてきた。このさい, 腫瘍細胞の動脈への侵入はきわ めてまれであり，本研究でも1例にみられたにすぎず (図 2)，したがって血管侵襲といってももっぱら静脈 が問題になる。欧米に比べ本邦で特異的に多い胃癌に ついては, 早くから由比 $(1954)^{3)}$, 浜崎 $(1967)^{4)}$, 永 友 $(1973)^{5)}$ ら研究がある。欧米では大腸癌について 古くはBrown \& Warren (1938)6), Sunderlund

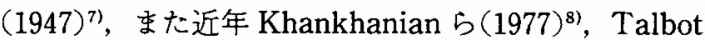
ら $(1981)^{910)}$ の研究があり, 本邦でもやや遅れて加藤 $(1979)^{11)}$, 雷 $(1979)^{12)}$, 志田 $(1980)^{13)}$, 阿兽 $(1981)^{14)}$, 陳 $(1983)^{15)}$, 小西 $(1983)^{16)}$, 田㴊 $(1983)^{17)}$ らの研究 がある。これらはその研究対象や方法などが異なるた めとらぜんその結果も一定でない。また本邦では大腸 癌取扱い規約は臨床家によりひろく使用されている

図 2 印環細胞癌 (上部直腸). 腫瘍細胞による動脈

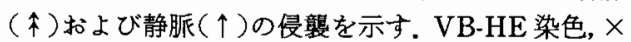
100

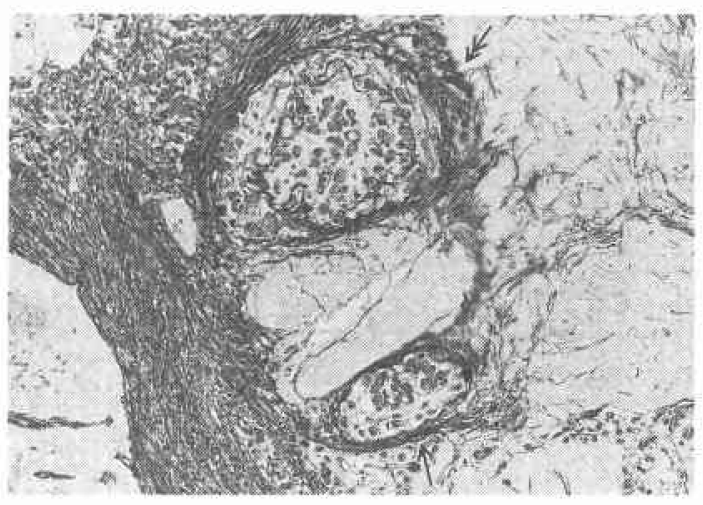

表 7 n因子と v 因子

\begin{tabular}{cc}
\hline $\mathrm{n}$ 因子 & 例 \\
\hline $\mathrm{n}_{0}$ & $30 / 78(38.4 \%)$ \\
$\mathrm{n}_{1}(\%)$ \\
$\mathrm{n}_{2}$ & $26 / 42(61.9 \%)$ \\
$\mathrm{n}_{3.4}$ & $24 / 32(75.0 \%)$ \\
\hline & $9 / 12(75.0 \%)$ \\
\hline
\end{tabular}


が，血管侵襲に関する記載はきわめて簡単であり，日 常の臨床に沏いて実際どの程度厳密に行われているか はなはだ疑問である。これらの点をふま兄て $2 ， 3 の$ 問題点について検討する。

1. 静脈侵襲の頻度之組織学的検査法

現在までに報告されている大腸癌における静脈侵襲 の頻度は研究者によりかなり異なるが(表 8), これは 検査対象や検查方法のちがいによる点が大きい，従来 の HE 染色では腫湯細胞による静脈侵襲の指標とし て, 内皮細胞の排列した腔内あるいは笳組織に囲まれ た腔内に持ける腫韵細胞が重視され，そのさい腔内に 赤血球の存在あるいは伴行する動脈の存在が有力な参 考所見とされてきた。しかし，これらの基準による判 定が不確実なことは明らかであり, 静脈の確認に弾力 線維の染色が必要なことはいうまでもなく,すでに Sunderlund ${ }^{7}$ によって指摘されていると捛りで，この ため Elastica van Gieson 染色（以下 EvG 染色）が奖 用されてきた。

小西 ${ }^{16)}$ は癌浸潤が固有筋層を越兄ている大腸癌 105 例について EvGの有用性を検討し, 腫瑒の中心部切片 1 個のみの検索の場合, $\mathrm{HE}$ のみでは静脈侵襲の検出 率は $19 \%$ にすぎないが, これに EvG 染色を併用すると

表 8 大腸癌に战ける静脈侵襲の頻度（文献報告）

\begin{tabular}{|c|c|c|c|c|c|c|}
\hline 者 & 年度 & 例数 &  & 㭘 索 対 象 & 㛟甞切片数 & 染色法 \\
\hline Khankanian & 1977 & 143 & 18.8 & Dukes $B$ & \multirow[b]{2}{*}{  } & \\
\hline Talbot & 1981 & 703 & 51.9 & 直 晹 应 & & $\mathrm{HE}$ \\
\hline 加 拏 & 1979 & 89 & 74 & ss擈 & 中心1 個 & $E \vee G$ \\
\hline 雷 & 1979 & 256 & 61 & 䊀渴·直晹壀 & 中心 1 蔨 & $E \vee G$ \\
\hline 志 田 & 1980 & 243 & 41 & 結脇·茞腷蓝 & 交叉2個 & \\
\hline 阿 曾 & 1981 & $\begin{array}{l}87 \\
68\end{array}$ & $\begin{array}{l}87 \\
78\end{array}$ & 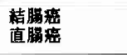 & $\begin{array}{l}\text { 中心 } 1 \text { 蔨 } \\
\text { 辺䄾 } 2 \text { 個 }\end{array}$ & $E \vee G$ \\
\hline 友 田 & 1981 & 28 & 26.1 & s既 & 全＼cjkstart割 & $E \vee G$ \\
\hline 陳 & 1983 & 201 & 34.8 & 結胆 · 直渴筑 & 全尌(6遇) & EvG \\
\hline 小 西 & 1983 & 113 & 88 & ss染 & 全＼cjkstart割 & $\mathrm{E} \vee \mathrm{G}$ \\
\hline 田 㴊 & 1985 & 358 & 35.8 & 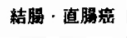 & 3個 & $\mathrm{E} \vee \mathrm{G}$ \\
\hline 林 田 & 1987 & $\begin{array}{l}26 \\
21\end{array}$ & $\begin{array}{l}38 \\
81\end{array}$ & $\begin{array}{l}\text { sm橆 } \\
\text { pris }\end{array}$ & 割 & $E \vee G$ \\
\hline 椋 棒 & 1987 & 71 & 19.7 & sm欂 & & \\
\hline 布 村 & 1987 & 63 & 29 & put庶 & & $E \vee G$ \\
\hline 黒 須 & 1987 & 22 & 22.7 & pats & & \\
\hline
\end{tabular}

$60 \%$ に上昇する結果を得て, EvGの必要性を強調して いる.さらに, 腫瘍中心部より切り出した切片に, こ れと平行する両側辺縁部より切り出した 2 本を加えた 3 本, 打上び腫瘍の全割切片（通常 6 本）について検 查し，HE染色のみではそれぞれ30\%，60\%，EvG染 色併用ではそれぞれ $79 \% ， 88 \%$ といら検出率を克，ル チーンの方法として腫瘍全体を含む切片を 3 本切り出 し, EvG 染色を行う方法が適当であろうと結論してい る、はなはだ妥当な意見といえる。

著者らの VB-HE 重染色では弾力線維が特異的に染 色され，他の組織は通常の HE 染色とまったく同様に 染色されるため, 通常の EvG 染色に比べきわめてみや すい利点がある(図 3，4)。しかし，このさいも静脈 に伴行する動脈の有無は重要な参考所見となる.

直腸癌の多数例について検索した Talbot ら9は,

図 3 高分化腺癌(横行結腸)。筋層中の侵襲静脈を示 す. HE 染色では識別不能である.VB-HE染色, $\times$ 100

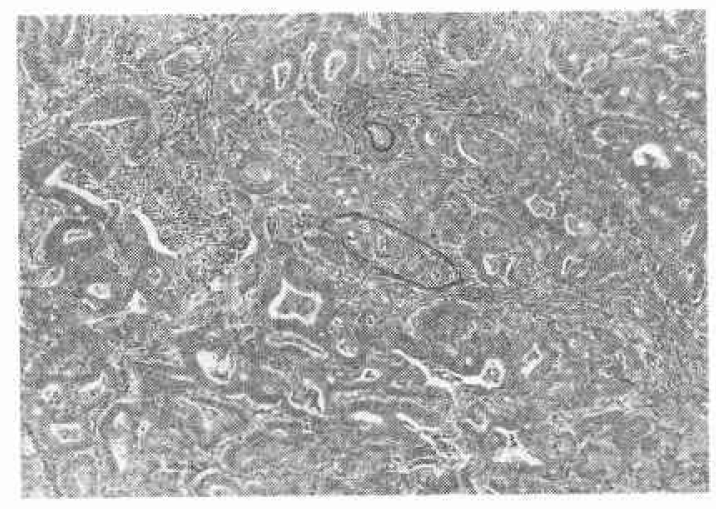

図 4 高分化腺癌(下部直腸). 静脈内腔の腫湯細胞は 周囲のリンパ管内の腫瘍細胞と容易に識別される. VB-HE染色, $\times 40$

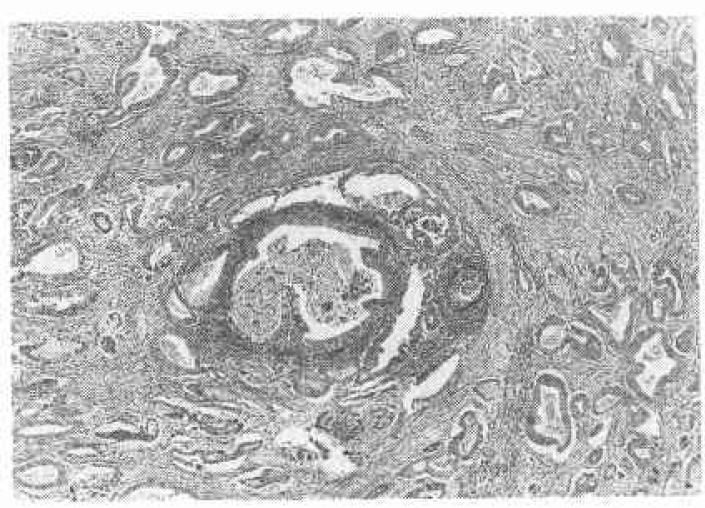


EvG 染色は有用であるが，ブロックより切片を追加作 製するためもとの HE 染色の標本と割面が異なるこ と,また直腸壁には EvGで染色される多量の弾力線維 があるためその有用性が限定されると述べている。彼 らの HE 染色のみによる検索結果は343例の Dukes'B 例で, 静脈侵襲検出率が $64 \%$ と良好であるが, 検索切 片数が小西と注注同じであることを考えると，その頻 度はかなり低いといえる。

弾力線維は静脈では口径 $200 \mu \mathrm{m}$ 程度の大きさから 出現するといわれ, 著者らの経験でもほぼ同様である. したがってこれより小さい静脈，とくに細静脈では弾 力線維染色も有効でない。このため細静脈の識別には 第V四因子関連抗原染色が有用と思われるが，著者らが 胃癌, とくに $\mathrm{m}$ 癌における静脈侵襲の検出に試みた経 験では，期待したほどの効果は得られなかった。した がって細静脈 (口径 $30 \mu \mathrm{m}$ 以下)の癌侵襲の検索は現在 まだ困難といえる。

検索する切片数がふえれば静脈侵襲の検出率が上昇 することは当然で, 前述した小西の成績よりみて明ら かである，著者らは原則として腫瘍の最深部かつ全長 を含む 1 切片のみについて検索したが, 畽汪の浸潤が 筋層を越えている138例ではその検出率は66\%となり， 小西の 3 本切り出し法に比べるとやはり低いが，ル チーンの検査法としては注満足すべきものと考えて いる.

\section{2. 静脈侵襲像の形態}

腫瘍細胞による静脈の侵襲像としては, 侵襲された 静脈の動脈瘤ようの抁張(図 5), 静脈腔内の腫瘍細胞 の壊死, 静脈壁の損傷に伴う静脈周辺の炎症性細胞浸

図 5 粘液癌(上部直腸)，粘膜下層の静脈は腫瘍細胞 の産生した粘液の貯留のため著明に拡張している。 VB-HE 染色, $\times 40$

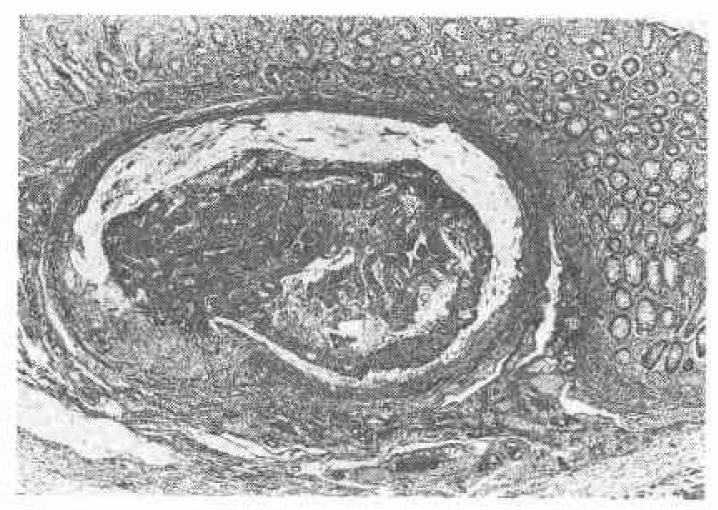

潤，あるいは肉芽組織や線維化による置換(図 6，7)， 増殖した内皮細胞に上る腫瘍細胞の被包, 腔内に遊離 した腫瘍細胞などの像があげられている。

雷 ${ }^{12)}$ はこれらを, (1) 静脈内腔閉塞型, (2) 静脈内腔 開通型，（3）静脈内遊離型に大別しているが, 後二者 については問題はないが, 閉塞型についてはその解釈 に異論がある。浜崎 ${ }^{4}$, 永友 ${ }^{51}$, 長尾ら ${ }^{18)}$ は胃癌につい てすでに同様の所見を記載しており, 長尾ら ${ }^{19}$ は, 腫瘍 細胞が静脈壁内に浸潤, 增殖し, その結果内腔が狭窄 され遂に閉塞したもの（圧迫性閉塞）之, 腫煌細胞の 塞栓により内腔が閉塞したもの (塞栓型閉塞) とを混

図 6 中分化腺癌(直腸 S 状部). 大きな静脈の内腔を 占める腫煬細胞は，異物型巨細胞を含む炎症性細胞 浸潤により被包されている。. a. VB-HE染色, $\times 10$, b. $\times 200$

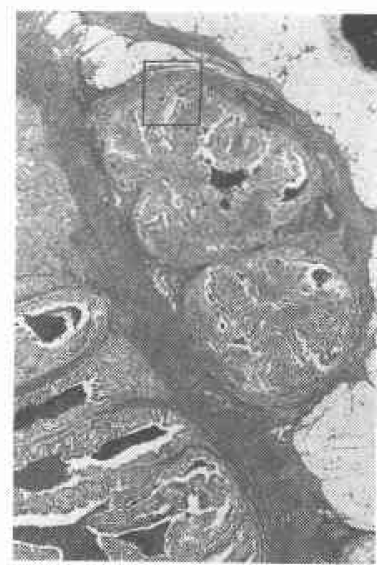

b

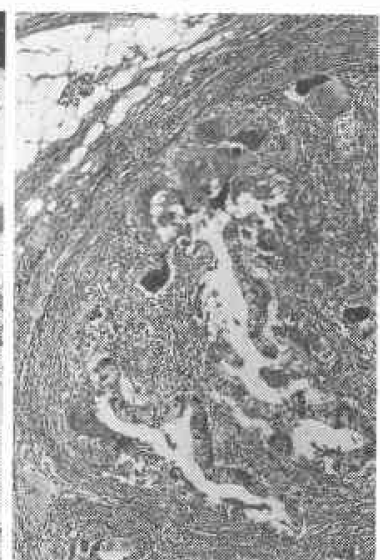

図 7 高分化腺癌 ( $\mathrm{S}$ 状結腸)。静脈内腔は結合織によ り充塞されているが,なかに腫煌細胞の浸潤がある. 動脈, 静脈とも elastosis が高度である. VB-HE 染 色, $\times 40$

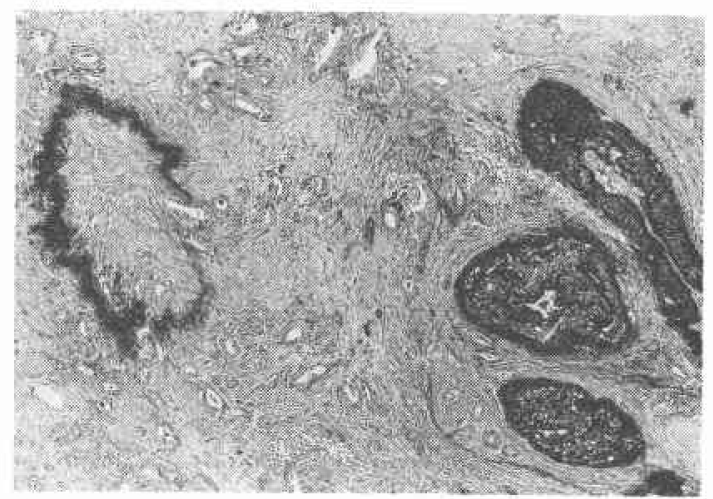


図 8 印環細胞癌 (S 状結腸)，静脈壁内に増殖した腫 瘍細胞の圧迫により内腔がほとんど閉塞しかけてい る. VB-HE染色, $\times 200$

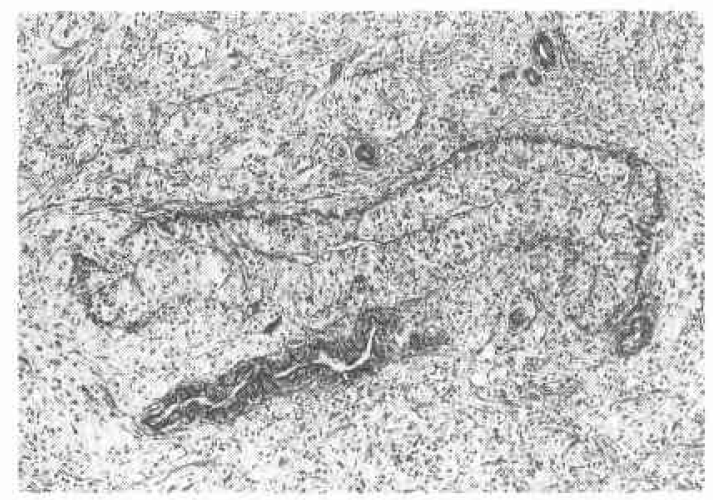

同しないよう注意する必要があることを指摘してい る. 長尾らはさらに，このような静脈壁が完全に破壊 され，内腔が腫摥細胞で充塞されているものは，血行 性肝転移のない例でもしばしばみられることから，ま た永友らも，このよらなるのはすでに血流が停止して いるため癌細胞の血中への移動は考えられないとし， いずれも静脈侵襲陽性例より除外したと述べている。 しかし，雷 ${ }^{12)}$ は連続切片による検索で, 同一の静脈でも 組織切片の採取部位により異なる侵襲像がみられるこ とから,このような型のものもすべて陽性としており， 著者らむこの見解に従った。

なお，雷は腫瘍細胞が静脈壁内のみに存在し内腔に 露呈していない場合も, 内膜直下にまで到達しておれ ば同様の考えのもとに陽性と判定したと述べている. このよらな像が印環細胞癌でしばしばみられることは 胃癌で指摘されて扣り ${ }^{355)}$ ，小西 ${ }^{16)}$ は大腸癌でも同様の ことを認めており, 著者らの検索でも認められた（図 8 ).

\section{3. 静脈侵襲の程度}

胃癌取扱い規約 ${ }^{19)}$ あるいは大腸癌取扱い規約 ${ }^{2)}$ に は，静脈侵襲の程度として $V_{1}$ より $V_{3}$ までに分類して いるが, その程度の判定基準として具体的な数值はあ げられていない. 雷 ${ }^{12)}$ は 1 切片内の全侵襲静脈が 1 $\sim 3$ 個の場合を軽度 $\left(V_{1}\right), 4 \sim 6$ 個を中等度 $\left(V_{2}\right)$, 7 個以上を高度 $\left(V_{3}\right)$ としている. 著者らは $1 \sim 2$ 個 を $V_{1}, 3 \sim 6$ 個を $V_{2}, 7$ 個以上を $V_{3}$ と規定した。雷 ${ }^{12)}$ はV 陽性例中 $\mathrm{V}_{1}$ が $81.4 \%$ で大部分を占め, $\mathrm{V}_{2}$ が $12.8 \%, \mathrm{~V}_{3}$ が $5.7 \%$ で, $\mathrm{V}_{2}$ 以上の静脈侵襲が手術例の約 $12 \%$ 占めたとしている。著者らの成績は $V_{1} 65.3 \%$,
$\mathrm{V}_{2} 23.4 \%, \mathrm{~V}_{3} 11.2 \%$ で, $\mathrm{V}_{2}$ の頻度が高いのは上述の 判定基準の差によると思われるが, 同じ基準の $\mathrm{V}_{3}$ の頻 度も雷 ${ }^{12)}$ ら高い.

\section{4. 侵襲静脈の大ささと局在}

解剖学的に, 静脈は大きさにより細静脈(口径15３0 $\mu \mathrm{m})$, 小静脈 ( $2 \mathrm{~mm}$ 以下), 中静脈 (2〜9mm) にわ的 られている。静脈は動脈と異なり，その長軸に対し直 角に横断されている場合です正円形を呈することはな く，横に長い棈円形を呈するため，その大きさをあら わすのに長径, 短径のいずれを測定するにしてす, 動 脈の場合泀ど簡単でない.もともと, 病理組織学的標 本では動脈でも収縮状態にあり，静脈の形も当然正常 之は異なるわけで, 切断方向や周辺の病変の有無に よって変形がさらに増強される、したがって真の大き さを判定するのはきわめて困難である，本研究ではこ のよらな点を考慮し, 測定䛊差を少なくするため短径 によりその大きさをあらわしたが，その数値は絶対的 なものではなく比較的なものにすぎない.

胃腸管壁に分布する静脈の大ささおよびその量的分 布などについては詳細な記載がない，一般には，粘膜 下層で血管分布がもっとも豊富であり，固有筋層では 少ないといわれるが，著者らの経験からも妥当と思わ れる、また，著者らの検索では粘膜下層では細ないし 小静脈が多く, しかも200 $\mathrm{m}$ (短径) 以上のものは少 なく, $1 \mathrm{~mm}$ 以上のbのはきわめてまれである。これに 反乙て，䵔膜下層ないし壁外では比較的大きな静脈が 多く, 1 2 $\mathrm{mm}$ の中静脈に近いものも少なくない. 大腸癌における侵襲静脈の大きさについての詳細な 記載はほとんどない. 志田ら ${ }^{13)}$ は100倍の検鏡で EvG 染色により確認でさる大きさの静脈のみについて検索 しており，雷 ${ }^{12)}$ 侵襲静脈は小静脈にかざられると述 ベているにすぎない。著者らは前述のように短径 200 $\mu \mathrm{m}, 200 \mu \mathrm{m} \sim 1 \mathrm{~mm}, 1 \mathrm{~mm}$ 以上の 3 段階の大きさにわ けて検討したが，やはり $200 \mu \mathrm{m}$ 以下のものがもっとも 多く, $200 \mu \mathrm{m}$ 以上のものは粘膜下層では少なく, $1 \mathrm{~mm}$ 以上の太いものは汪とんど浆膜下層ないし壁外にかぎ

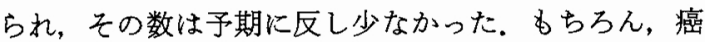
の侵襲をうけた静脈はしばしば拡張し、いわゆる動脈 瘤ようのものも少なくなく，真の大きさを判定するの は困難である、したがって，上述の分類も絶対的なる のではないが大体の傾向を示しているといえる．Talbotら”は口径の大きさによらず，静脈壁の厚さによっ て2つに分類しているが，これる上述と同様に絶対的 なものではない. 
侵襲をらける静脈は粘膜下層でもっとも多いという 報告12141415) あるが，著者らの検索では粘膜下層と奖 膜下層ないし壁外が注注同様の頻度で多く，筋層では もっとも少なかった。この点, 胃癌で粘膜下層で奖膜 下層より著明に多かったのと対照的であった。なお, 20例 (20.4\%) では 2 層以上に認められたが, 雷は約 3 分の 1 の症例に重複がみられたと述べている。これ ら重複例む粘膜下層之奨膜下層の両者に認められたも のが大部分を占めていた。これは前述のよ5に血管分 布に関係するむのと思われる.

5. 静脈侵襲とその他の組織所見

1) 癌組織型之静脈侵襲

大腸癌の組織型でもっとも多いのは高分化腺癌であ り,この点, 胃癌で低ないし中分化腺癌が多いのと対 照的である. 著者らの検索では静脈侵襲の頻度は高分 化腺癌と中分化腺癌の間に差がなかったが, 後者の方 が高いとする報告もある(2)15). 粘液癌, 低分化腺癌は例 数が少ないため推計学的に検討しえなかった.

2) 癌深達度と静脈侵襲

癌の深達度がすすむとともに静脈侵襲の頻度が上昇 することは当然予想されることで, 著者らの成績を含 め他の研究者の成績も一致している，著者の胃癌につ いての同様の検索では, $\mathrm{m}$ 癌 55 例で静脈侵襲は 1 例も 認められなかった。大腸の $\mathrm{m}$ 癌は活とんどすべて隆起 型であり, 静脈侵襲の可能性はより少ないと考えられ るし，また内視鏡的に切除された例もあるため今回の 検索対象から除外した.

$\mathrm{sm}$ 癌では約 3 分の 1 に静脈侵襲が認められたが, 同様の検索で友田ら ${ }^{201}$ は28例で26.1\%，林田ら ${ }^{21}$ は26 例で38\%，また椋棒 ${ }^{22}$ は71例で19.7\%といら頻度をあ げている，椋棒の症例はポリペクトミ一例が37例含ま れており，そのうち24例は二期的に腸切除をらけてい るが，いずれにしても比較的表在性のものが多いため 低値を示したものと思われる。

著者らの症例では例数が少ないためか, $\mathrm{pm}$ 癌では 静脈侵襲の頻度が $22.8 \%$ で $\mathrm{sm}$ 癌よりもむしろ低値で あった。雷 ${ }^{12)}$ は35\%，布村 ${ }^{23)}$ は29\%，黒須ら ${ }^{24)} 22.7 \%$ といずれも低值を示しているが，林田 ${ }^{211}$ のが $81 \%$ と いう高値をあげている。これは検査方法のちがいによ るものと思われるがな打詳細な検討が望ましい,

\section{3）リンパ管侵襲と静脈侵㜔}

リンパ管侵襲の有無之静脈侵襲の頻度は推計学的に 有意の差があったが, 両者の程度は必らずしも平行し ていなかった。雷 ${ }^{12)}$ は中等度以上のリンパ管侵襲例で
はほとんど全例に静脈侵襲が認められ，しかも $\mathrm{V}_{2} や$ $\mathrm{V}_{3}$ 例との合併例がかなり多くみられたという。しか し，リンパ管侵襲の程度は具体的数值で表現しえず, 主観に左右される抏それもあり，断定するのは困難で あろう。いずれにしても，リンパ管侵襲の陰性例でむ 約 3 分の 1 に静脈侵襲が認められたことは注目に值す る所見といえる。

4）リンパ節転移と静脈侵襲

リンパ管侵襲の場合と同じく，リンパ節転移の有無 と静脈侵襲の間には有意の相関があり，またその程度 もよく平行している，また，転移陰性例の約 $40 \%$ 近く に静脈侵襲が認められたことは注目に値する所見とい える.

\section{6. 血行性転移之静脈侵襲}

大腸癌では胃癌に比べ高頻度に血行性転移, とくに 肝転移をきたすことはよく知られており，臨床例では 観察期間によるが開腹時すでに10 20\%に認めら

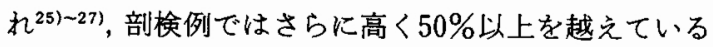
報告が多い28). また, 結腸癌と直腸癌での発生率は報告 者により異なり絶対的なことはいえないようである. 著者らの症例では手術時に13.6\%に認められて招り諸 家の報告の範团内にある。

肝転移々原発巣の静脈侵襲とは関連が深く, 静脈侵 襲のある例はない例に比べ明らかに高く，また肝転移 例の大多数で原発巣に静脈侵襲が認められることは諸 家の意見が一致している. Talbot ら"1は直腸癌で, 侵 刻静脈が粘膜下層あるいは筋層内にある昜合よりる壁 外にある場合，また壁の薄い静脈よりむ厚い静脈に侵 襲のある場合に, 肝転移の発生率が高く両者の間に相 関が強いことを指摘している. 本邦でも，加藤 ${ }^{16)}$ ，志 田 $^{13)}$, 田㴊ら ${ }^{17}$ は粘膜下層にみられる静脈侵襲は肝転 移には影響せず，奖膜下層のものがより意義があると し, 陳 ${ }^{15}$ は粘膜下層あるいは将膜下層単独では関係な く, 両者に存在する場合に肝転移が高率になるとして いる。 また，雷 ${ }^{12)}$ は剖検例の肝転移の検索で, 静脈侵襲 が中等度以上の例，また将膜下層あるいは壁外に存在 する例が多かったと述べているが，肝転移陰珄例でも 静脈侵襲の認められる例も少なくないことを注意して いる.

著者らの症例では前述のように，肝転移を有する 24 例中 1 例をのぞき全例に原発巣に静脈侵襲が認められ たが，侵襲の程度の強いものほど肝転移も高度で，侵 襲静脈の局在では将膜下層ない乙壁外にある場合に高 い傾向がみられたが，静脈の大きさでは予期に反し L 
がなく，また組織型でも高分化と中分化腺癌の間に有 意差がなかった。

な拈，術後経過中に明らかな肝あるいは肺転移をき たしたものが，それぞれ 8 例と 4 例( 万ち 1 例は重複) あるが，これらの症例で原発巣に静脈侵襲の認められ たものはそれぞれ 6 例と 3 例(5ち 1 例は重複)，すな わち血行性転移をきたした11例中 8 例に静脈侵襲が認 められた。

\section{7. 静脈侵襲と生存率}

静脈侵襲陽性例が陰性例に比べ長期予後が悪いこと は，汪とんどすべての報告例が一致して述べてお $\eta^{1012213115) 17729)}$ ，著者らの症例でも両群間には著明な 差がみられた。ただ, Khankhanian ら゙タ, Dukes'Bの 大腸癌143例の検索で, 静脈侵襲の有無は予後と関係な いとしているが, HE 染色のみによる検索であり，かつ 全体の陽性率もかなり低いので信頼できない.

8. 胃癌と大腸癌に和汀る静脈侵襲の比較

著者らはさきに岐阜大学医学部第 1 外科教室に扔い て, 今回の症例と同期間に切除された胃癌235例につい て，今回とまったく同様の方法により胃癌組織の静脈 侵襲について検索した(詳細は別報の予定). その結果 を主な点について大腸癌と比較すると表 9 のようにな る.235例の胃癌全体として静脈侵襲の陽性率は $37.0 \%$ であったが $\mathrm{m}$ 癌 55 例では静脈侵壟が 1 例も認められ なかったので，これを除外すると $48.3 \%$ となる。すな わち, 肝転移の頻度の高い大腸癌では胃癌に比べ静脈 侵襲率が高いと予測されたが，両者の間に有意の差が 認められなかったのはやや意外であった。 また，侵襲 静脈の大ささおよびその頻度にも差はなかったが，そ の局在には明らかならがいがあり，このことが大腸癌 に招いて肝転移を起こしやすい一因と考兄られる。亦

表 9 胃癌と大腸癌における静脈侵襲（v）の比較

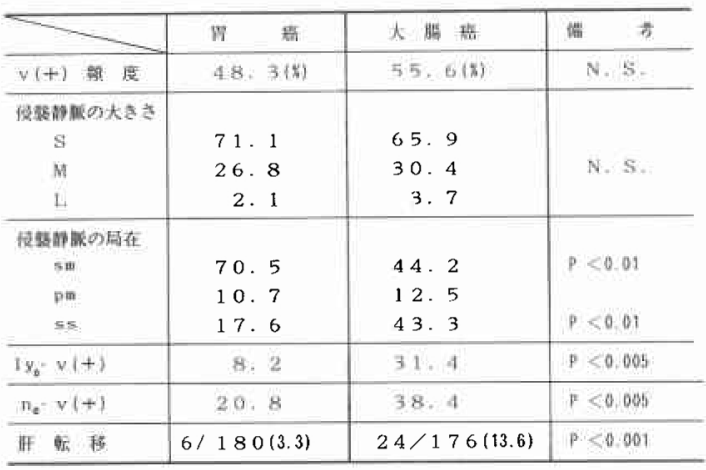

た両者ともリンパ管侵襲陰性例ならびにリンパ節転移 陰性例のいずれにも, 静脈侵襲陽性例が認められたが, その頻度は大腸癌に扔いて明らかに高く, この点から も大腸癌では胃癌の場合よりも静脈侵襲の意義が大き いといえる。

$$
\text { まとめ }
$$

大腸癌切除例185例のうち $\mathrm{m}$ 癌 9 例を除く 176 例に ついて, 静脈侵襲に重点を括いて病理組織学的検索を 行い次の結果を得た。

1. 静脈侵襲は176例中98例 (55.6\%) に認められた。 その程度は軽度のものが 3 分の 2 を占めていた。

2. 侵襲静脈は短径 $200 \mu \mathrm{m}$ 以下のものが約 3 分の 2 で, $1 \mathrm{~mm}$ 以上の太いものはきわめて少数であった。侵 襲静脈は粘膜下層および奖膜下層ないし壁外で注ぼ同 頻度に存在し, 後者ではとくに $200 \mu \mathrm{m} \sim 1 \mathrm{~mm}$ のの が多く認められた。

3. 静脈侵襲は組織型では低分化ならびに中分化腺 癌でやや高率であった。

4. 静脈侵襲は癌の深達度に並行して増加するのが 認められた。

5. 静脈侵襲はリンパ管侵襲あるいはリンパ節転移 と相関し, これらの陰性例と陽性例では有意の差がみ られた。

6. 静脈侵襲陽性例は陰性例に比べ予後が有意に不 良であった。

7. 原発巣の静脈侵襲は肝転移の発生に密接な関係 があるが，な打他の因子の関与る疑われた。

8. 静脈侵襲の程度, 侵襲静脈の局在, リンパ管侵襲 およびリンパ節転移などとの関連より，大腸癌では胃 癌よりも静脈侵襲の臨床的意義がより大きいことが示 唆された。

9. VB-HE 重染色は静脈侵襲の識別に通常の EvG 染色よりはるかに優れた方法であることを確認した。

本論文の要旨は第 42 回日本大腸肛門病学会総会において 発表した.

稿を終えるにあたり，研究方法について御教示いただい た昭和大学医学部外科片岡徹助教授, 標本作製に御協力 いただいた本学中央検查部丸本雅夫技師に深謝します。

\section{文献}

1）横川和子, 大橋ひろみ, 加藤 洋：ビクトリアブ ルー・H・E染色. 臨検査 $27: 571-572 ， 1983$

2）大腸癌研究会編：大腸癌取扱い規約. 第 4 版. 金原 出版, 東京, 1985

3）由比貞勝：胃癌胃における血管変化に関する組織 学的研究。扮茶の水医誌 $5: 88-107,1957$ 
4）浜崎美景, 難波正義, 藤田 甫ほか：胃癌の血管侵 襲について一および脈管侵襲による grading と予 後。細胞核病理誌 $11: 107-112,1967$

5）永友知英，村上栄一郎：胃癌における血管侵襲の 臨床病理学的研究, 癌の臨 $19: 206-214,1973$

6) Brown CE, Warren $S$ : Visceral metastases from rectal carcinoma. Surg Gyencol Obstet $66: 611-621,1938$

7) Sunderlund DA : The significance of vein invasion by cancer of the rectum and sigmoid. Cancer 2: 429-437, 1949

8) Khankhnian N, Mavlight GM, Russel WO et al : Prognostic significance of vascular invasion in colorectal cancer of Dukes'B class. Cancer 39 : 1195-1200, 1977

9) Talbot I, Ritchie S, Leighton $\mathrm{MH}$ et al: The clinical significance of invasion of veins by rectal cancer. Br J Surg 67 : 439-442, 1980

10) Talbot I, Richie S, Leighton MH et al: Spread of rectal cancer within veins. Histologic features and clinical significance. Am J Surg 141 : $15-17,1981$

11）加藤 洋, 菅野晴夫, 中算恭一ほか：大腸暚切除標 本に扣ける静脈侵睡 $\left(\mathrm{V}_{+}\right)$の評価一特に墏膜下静 脈侵襲について。 日本大腸肛門病会誌 32 ： $73-74,1979$

12）雷 金湲：大腸癌に括汀る静脈侵襲に関する病理 組織学的研究. 福岡医誌 $70: 491-512,1979$

13）志田晴彦, 久保脈自, 坂本昌義注か：大腸癌の漿膜 下静脈侵襲と肝転移に関する臨床病理学的研究. 日外会誌 $82: 277-283,1980$

14）阿曽弘一, 高根俊毅, 五十嵐正厇ほか：大腸癌と脈 管侵襲. 日臨 $39: 2158-2163 ， 1981$

15）陳 文夫：大腸癌の病理組織学的研究一とくに血 管侵㻤と予後を中心として一. 千葉医誌 $59: 237$ $-247,1983$
16）小西文雄：大腸癌の静脈侵襲に関する臨床病理学 的研究. 日消病会誌 $80: 1599-1609,1983$

17）田㴊芳樹, 中江史朗, 今西築汪か：大腸癌術後血 行性転移再発に関する臨床的・病理学的研究一特 にその予知と抑制に関する検討一。扑会誌 $85: 1359-1369,1985$

18）長尾孝一, 松哿 理, 井出源四郎：胃癌原発巣にお ける血管の態度．癌の臨 $21: 103-109,1975$

19）胃癌研究会編：胃癌取扱い規約。第11版。金原出 版，東京， 1985

20）友田 潔, 岩下明徳, 遠城寺宗知：大腸 sm 癌の検 討. 癌の臨 $27: 1613-1616,1981$

21）林田啓介, 磯本浩明, 白本和雄注か：大腸 sm 癌の 検討一とくに脈管侵襲と簇出について一。日本大 腸肛門病会誌 $40: 119-126,1987$

22）椋棒 豊：大腸 sm 癌に対する治療方針の検討。 日本大腸肛門病会誌 $40: 361-368,1987$

23）布村正夫：大腸 $s m$ 癌の臨床病理学的研究. 日本 大腸肛門病会誌 $49: 755-765,1987$

24）黑須康彦, 中西 浩, 森田 健：大腸 pnm 癌の臨 床病理学的検討。日本大陽肛門病会誌 40 ： $862-865,1987$

25）毛受松寿, 堅村 明：結腸・直腸癌と肝転移。外科 診療 $31: 201-207,1974$

26）藤本 茂, 宮崎 勝, 橘川征夫ほか：肝転移。癌の 臨 $27: 1014-1020,1981$

27）関根 毅, 須田 夫：大腸癌肝転移症例の検討 一臨床病理学的所見と遠隔成績を中心に一。消 外会誌 $18: 2368-2374,1985$

28）雷 金湲，遠城寺宗知：大腸癌の浸潤転移状況々 原発巣の静脈侵浸。福岡医誌 $71: 417-423,1980$

29) Jass JR, Atkin WS, Cuzick J et al: The grading of rectal cancer: Histological and a multivariate analysis of 447 cases. Histopathology $10: 437-459,1986$ 